\title{
Designing optimal greenhouse gas monitoring networks for Australia
}

\author{
T. Ziehn ${ }^{1}$, R. M. Law ${ }^{1}$, P. J. Rayner ${ }^{2}$, and G. Roff ${ }^{3}$ \\ ${ }^{1}$ CSIRO Oceans and Atmosphere Flagship, Aspendale, VIC 3195, Australia \\ ${ }^{2}$ School of Earth Sciences, University of Melbourne, Melbourne, VIC 3010, Australia \\ ${ }^{3}$ Australian Bureau of Meteorology, Docklands, VIC 3008, Australia \\ Correspondence to: T. Ziehn (tilo.ziehn@csiro.au)
}

Received: 30 June 2015 - Published in Geosci. Instrum. Method. Data Syst. Discuss.: 5 August 2015

Revised: 18 December 2015 - Accepted: 4 January 2016 - Published: 19 January 2016

\begin{abstract}
Atmospheric transport inversion is commonly used to infer greenhouse gas (GHG) flux estimates from concentration measurements. The optimal location of groundbased observing stations that supply these measurements can be determined by network design. Here, we use a Lagrangian particle dispersion model (LPDM) in reverse mode together with a Bayesian inverse modelling framework to derive optimal GHG observing networks for Australia. This extends the network design for carbon dioxide $\left(\mathrm{CO}_{2}\right)$ performed by Ziehn et al. (2014) to also minimise the uncertainty on the flux estimates for methane $\left(\mathrm{CH}_{4}\right)$ and nitrous oxide $\left(\mathrm{N}_{2} \mathrm{O}\right)$, both individually and in a combined network using multiple objectives. Optimal networks are generated by adding up to five new stations to the base network, which is defined as two existing stations, Cape Grim and Gunn Point, in southern and northern Australia respectively. The individual networks for $\mathrm{CO}_{2}, \mathrm{CH}_{4}$ and $\mathrm{N}_{2} \mathrm{O}$ and the combined observing network show large similarities because the flux uncertainties for each GHG are dominated by regions of biologically productive land. There is little penalty, in terms of flux uncertainty reduction, for the combined network compared to individually designed networks. The location of the stations in the combined network is sensitive to variations in the assumed data uncertainty across locations. A simple assessment of economic costs has been included in our network design approach, considering both establishment and maintenance costs. Our results suggest that, while site logistics change the optimal network, there is only a small impact on the flux uncertainty reductions achieved with increasing network size.
\end{abstract}

\section{Introduction}

Carbon dioxide $\left(\mathrm{CO}_{2}\right)$, methane $\left(\mathrm{CH}_{4}\right)$ and nitrous oxide $\left(\mathrm{N}_{2} \mathrm{O}\right)$ are the three most important greenhouse gases (GHGs), and they amount to $80 \%$ of the total current radiative forcing from well-mixed GHGs. Their concentrations in the atmosphere have increased since pre-industrial times by $40 \%$ for $\mathrm{CO}_{2}, 150 \%$ for $\mathrm{CH}_{4}$ and $20 \%$ for $\mathrm{N}_{2} \mathrm{O}$. Their combined increases are the main driver for climate change (Ciais et al., 2013). It is therefore important to monitor major GHGs, not only for the continuous observation of atmospheric concentrations to detect global trends, but also for deriving better constrained budgets and a better attribution of the flux components.

Surface fluxes can be derived, for example, by running a process-based model in forward mode, where atmospheric concentration measurements have been used to constrain model parameters. This has been successfully demonstrated for $\mathrm{CO}_{2}$ in the form of the Carbon Cycle Data Assimilation System (CCDAS) (Rayner et al., 2005; Ziehn et al., 2011). However, the most commonly used tool for deriving surface fluxes on multiple temporal and spatial scales has been atmospheric transport inversion (e.g. Gurney et al., 2002; Peylin et al., 2013). Both approaches rely heavily on accurate measurements from observing stations.

A global network of ground-based measurement stations has been developed over the years to monitor $\mathrm{CO}_{2}, \mathrm{CH}_{4}$ and $\mathrm{N}_{2} \mathrm{O}$. The Global Atmosphere Watch (GAW) programme of the World Meteorological Organization (WMO), for example, coordinates activities on greenhouse gas observations, including quality assurance, calibration, validation and archiving of data for climate research purposes. Stations are 
actively hosted by more than 80 countries around the world (WMO, 2014). Most of these stations perform flask sampling only (selected for background conditions), but continuous insitu data are becoming increasingly available.

Network design studies can be used to provide guidance on how to extend existing observational networks in an optimal way, particularly as new types of instruments or measurements become available. One major advantage of network design is that stations can be assessed where no data are available yet and potential new stations can be added to the network by minimising a defined cost function. Most GHG network design studies have been performed for $\mathrm{CO}_{2}$ only (e.g. Rayner et al., 1996; Law et al., 2004). However since current-generation instruments now typically measure more than one GHG, and logistical benefits are derived from co-locating instruments, it is helpful to extend the $\mathrm{CO}_{2}$-only studies to consider the network design requirements for the three major GHGs together.

We focus our study on the Australian continent and use the methodology developed by Ziehn et al. (2014), although the method could equally be applied to other regions (e.g. Nickless et al., 2015, for South Africa). We consider continuous concentrations measurements for all three GHGs at an hourly timescale, which results in a network that could be used to derive surface fluxes at a high spatial and temporal resolution. Australia is an interesting case study since it is a large, mostly sparsely populated, continent with only a small current GHG observing network compared to other continents such as North America and Europe. Haverd et al. (2013) noted that global inversions provided no meaningful constraint on the Australian carbon budget due to limited observations that were usually selected for background (i.e. ocean not continental) conditions. Hence, given resource constraints, it is vital that any additional measurement capability be targeted not only at locations with the greatest potential to reduce flux uncertainties across the three GHGs but also at locations that are logistically feasible and minimise ongoing maintenance costs. For this reason the network design process applied here is based on pre-selected potential locations, chosen for their existing infrastructure. We also test the sensitivity to a simple accessibility measure which would be a likely contributor to ongoing maintenance costs. Establishment and maintenance costs have also been considered in a network design study for a synthetic greenhouse gas in California (Lucas et al., 2014). While they did not pre-select locations, the establishment cost was chosen to be smaller for locations near to existing sites, while maintenance cost was related to measurement frequency (a factor that we do not consider to be relevant for our application).

\section{Methodology}

The approach used in this study for the network design is based on a combination of Bayesian inverse modelling methodology applied to an atmospheric transport model. We only provide a short summary of the methodology here and refer for details to Ziehn et al. (2014).

A simple linear expression can be used to represent the relationship between surface fluxes $(\boldsymbol{f})$ and modelled concentrations $\left(\boldsymbol{c}_{\mathrm{mod}}\right)$ :

$c_{\text {mod }}=c_{\text {mod }_{\mathrm{f}}}=\mathbf{T} \boldsymbol{f}$,

where $\mathbf{T}$ is the transport or sensitivity matrix which needs to be determined. If we omit contributions from outside the region of interest and the initial conditions, then our modelled concentrations are derived from surface fluxes only, i.e. $\boldsymbol{c}_{\text {mod }}=\boldsymbol{c}_{\text {mod }_{\mathrm{f}}}$.

Using a Bayesian synthesis inversion scheme (Tarantola, 1987; Enting, 2002) and assuming a Gaussian error distribution for the surface fluxes and concentrations, we obtain the maximum likelihood estimated for $f$ by minimising the following cost function:

$$
\begin{aligned}
& J(\boldsymbol{f})=\frac{1}{2}\left(\left(\boldsymbol{c}_{\mathrm{mod}}-\boldsymbol{c}\right)^{\mathrm{T}} \mathbf{C}_{\boldsymbol{c}}^{-1}\left(\boldsymbol{c}_{\mathrm{mod}}-\boldsymbol{c}\right)\right. \\
& \left.+\left(\boldsymbol{f}-\boldsymbol{f}_{0}\right)^{\mathrm{T}} \mathbf{C}_{\boldsymbol{f}_{0}}^{-1}\left(\boldsymbol{f}-\boldsymbol{f}_{0}\right)\right),
\end{aligned}
$$

where $\mathbf{C}_{\boldsymbol{c}}$ is the error covariance matrix of the observations, vector $\boldsymbol{f}_{0}$ contains prior flux estimates, vector $\boldsymbol{f}$ represents predicted fluxes and $\mathbf{C}_{f_{0}}$ is the prior error covariance matrix of the surface fluxes.

The solution of the optimisation problem expressed through the cost function in Eq. (2) provides optimal surface fluxes based on the observations provided and also posterior uncertainties for the GHG fluxes expressed through the posterior covariance matrix $\mathbf{C}_{\boldsymbol{f}}$. For the network design approach we are only interested in the latter, because our aim is to find a network (set of observations) that minimises the surface flux uncertainties. The posterior covariance matrix can be calculated by (Tarantola, 1987)

$\mathbf{C}_{\boldsymbol{f}}=\left(\mathbf{T}^{\mathrm{T}} \mathbf{C}_{\boldsymbol{c}}^{-1} \mathbf{T}+\mathbf{C}_{f_{0}}^{-1}\right)^{-1}$

Incremental optimisation is then applied to design a network by adding one location at a time, with each new location chosen to minimise the network design cost function. The network design cost function (Sect. 3.1) is calculated based on the posterior flux uncertainties.

As noted by Hardt and Scherbaum (1994), the calculation of the posterior flux uncertainties does not depend on a particular value of the surface fluxes or concentration observations. It only depends on the transport model, the prior flux uncertainties and observational uncertainties. We discuss each in turn.

\subsection{Transport model}

The relationship between surface fluxes and atmospheric concentrations is calculated using the Lagrangian Particle 
Dispersion Model (LPDM) (Uliasz, 1994), which we run in reverse mode for each potential and existing measurement station we would like to include in the network design process. Particles are released (from the known or proposed measurement height) every $20 \mathrm{~s}$ for a total of four weeks for all four seasons of the year, and the particle's position is recorded at $15 \mathrm{~min}$ intervals. Particles that are near the surface are counted for each grid cell to determine the surface influence or sensitivity, from which a source-receptor relationship can be defined (Seibert and Frank, 2004; Ziehn et al., 2014) as

$$
\frac{\partial \bar{\chi}}{\partial \dot{q}_{\text {in }}}=\frac{\Delta T g}{\Delta P} \overline{\left(\frac{N_{\text {in }}}{N_{\text {tot }}}\right)} \frac{M_{\text {air }}}{M_{x}} \times 10^{6},
$$

where $\bar{\chi}$ is a volume mixing ratio (receptor) and $\dot{q}_{\text {in }}$ is a mass flux density (source). $N_{\text {in }}$ is the number of particles in a grid element (source) at each time interval $\Delta T$, and $N_{\text {tot }}$ is the total number of particles released during a time interval. The overbar indicates temporal averaging over the time interval $\Delta T . \Delta P$ is the pressure difference in the surface layer, and $g$ is the gravity of Earth. $M_{\text {air }}$ represents the molecular mass of air, and $M_{x}$ is the molecular mass of our quantity of interest, which is carbon $\mathrm{C}$ and nitrogen N. Other than the molecular mass scaling the source-receptor relationships are the same for all three greenhouse gases, on the assumption that any atmospheric loss of $\mathrm{CH}_{4}$ or $\mathrm{N}_{2} \mathrm{O}$ will have a negligible impact on the spatial pattern of surface influence over the relatively short periods being modelled.

LPDM requires meteorological driving fields, which are provided in this study by the regional version of the Australian Community Climate and Earth System Simulator (ACCESS-R) (NMOC, 2013) at $12 \mathrm{~km}$ resolution for the Australian region at an hourly timescale. Driving data include the 3-D wind field, temperature and turbulent kinetic energy (TKE) at 39 vertical levels up to $18 \mathrm{~km}$ in height. Ziehn et al. (2014) only calculated source-receptor relationships for one summer and one winter month. Here, we also run LPDM for the intermediate seasons and calculate sourcereceptor relationships for January, April, July and October.

Since LPDM is run over a limited area, any boundary effects need to be assessed. This was done by Ziehn et al. (2014), who found that the uncertainty contribution of the boundary concentrations to the uncertainty of the observations could be considered negligible. That assessment was generic and hence is equally as applicable to $\mathrm{CH}_{4}$ and $\mathrm{N}_{2} \mathrm{O}$ as $\mathrm{CO}_{2}$, and therefore we do not include boundary concentrations in the network design process.

As stated in Ziehn et al. (2014) the contribution from the initial conditions are also negligible, because they are very well constrained by the observations and their contribution to the flux uncertainty is therefore thought to be small.

\subsection{Prior flux uncertainties}

The Bayesian inversion method requires an estimate of the prior surface flux uncertainties, which are incorporated in the error covariance matrix for prior surface fluxes. Here, we do not consider correlations between different fluxes, which means the error covariance matrix only has elements in the diagonal. The effect of temporal correlations for the same grid cell and spatial correlations for neighbouring grid cells for surface fluxes was investigated by Nickless et al. (2015), and they found that the correlation structure has a significant impact on the results of the network design. However, in order to include correlations in the prior error covariance matrix, one needs to be confident in the size and structure of those correlations (Rayner, 2004). Including, for example, correlations that are too large can lead to an overly constrained system (Lauvaux et al., 2012; Nickless et al., 2015). We therefore decided to assume independence between prior fluxes.

The prior flux uncertainties are provided at a weekly temporal resolution and separately for daytime and nighttime, consistent with the weekly temporal resolution at which fluxes are estimated. Flux uncertainties are expressed as 1 standard deviation.

\subsection{1 $\mathrm{CO}_{2}$ prior flux uncertainties}

For the prior $\mathrm{CO}_{2}$ surface flux uncertainties we consider contributions from the terrestrial biosphere and from fossil fuel combustion. The biosphere flux uncertainties are estimated based on modelled net primary productivity (NPP) using the following simple relationship (Chevallier et al., 2010):

$\sigma_{\mathrm{NEP}}=\min \left(4 \mathrm{~g} \mathrm{Cm}^{-2} \mathrm{day}^{-1}, \mathrm{NPP}\right)$,

where NEP is the net ecosystem productivity (net carbon flux). NPP is derived for the Australian continent from BIOS2 model simulations (Haverd et al., 2013) at a daily timescale. BIOS2 is a modelling framework that uses the Community Atmosphere Biosphere Land Exchange (CABLE) model (Wang et al., 2010) at $5 \mathrm{~km}$ resolution $\left(0.05^{\circ} \times\right.$ $\left.0.05^{\circ}\right)$. We then aggregate the high-resolution fluxes to the resolution that we use for the network design $\left(1.8^{\circ} \times 1.8^{\circ}\right)$ and estimate the uncertainties for NEP according to Eq. (5) for each week divided into day- and night-time (Fig. 1).

Fossil fuel uncertainties are derived from the Fossil Fuel Data Assimilation System (FFDAS) (Rayner et al., 2010; Asefi-Najafabady et al., 2014). We use 10 realisations from FFDAS version II at $0.1^{\circ} \times 0.1^{\circ}$, aggregate them to our network design resolution and then calculate the uncertainties from the 10 realisations. Due to the fact that fossil fuel fluxes are derived on the basis of power plant locations and night lights, they are very localised and vary a lot in magnitude. As pointed out in Ziehn et al. (2014), an aggregation of those high-resolution fluxes to the network design resolution results in fluxes which are much smoother and with uncer- 

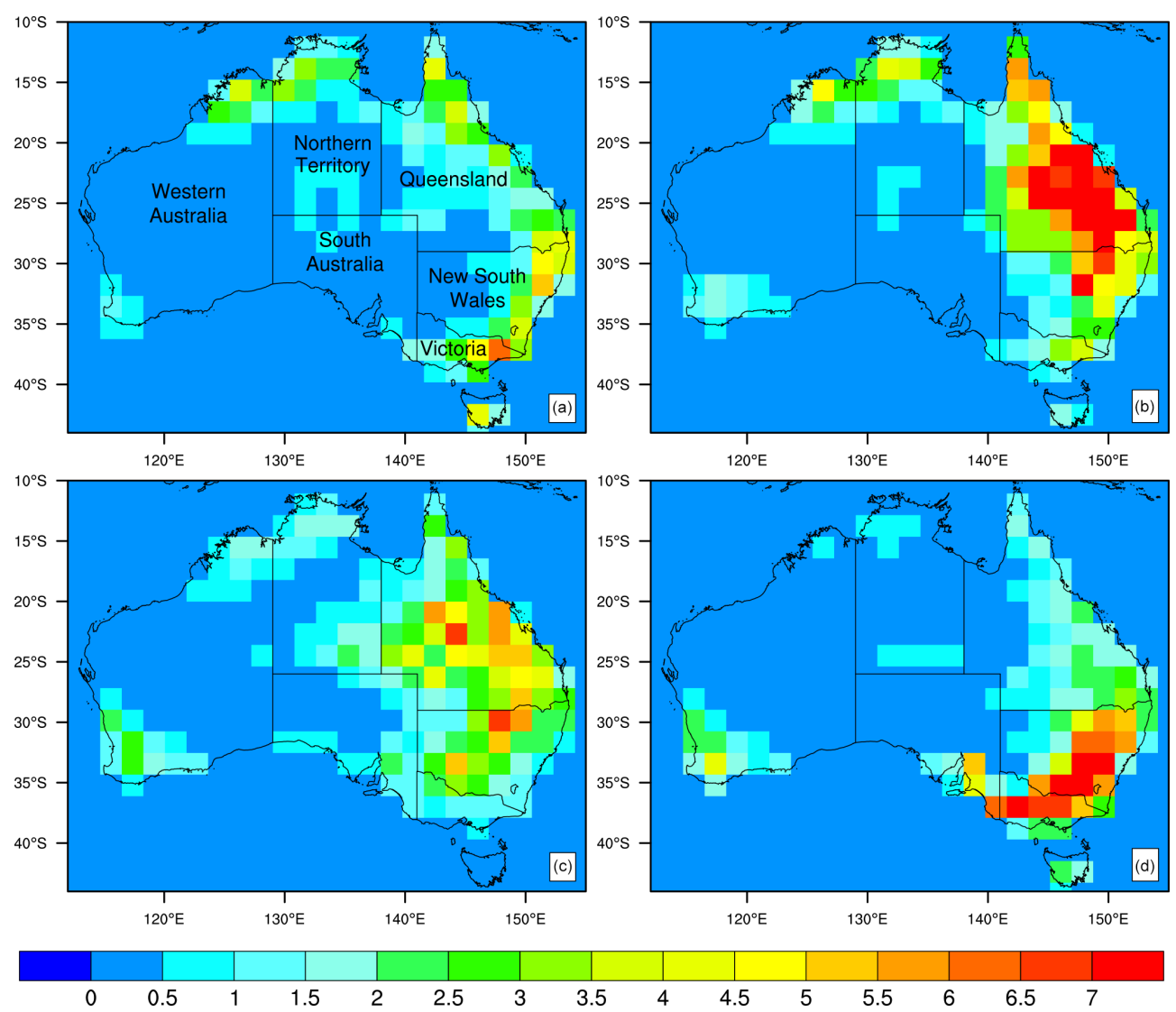

Figure 1. Prior biosphere $\mathrm{CO}_{2}$ flux uncertainties (1 standard deviation) in grams carbon per square metre per week at $1.8^{\circ}$ resolution for the first week in (a) January, (b) April, (c) July and (d) October.

tainties much smaller than the uncertainties from the biosphere fluxes. Therefore, the total surface flux uncertainties are dominated by the uncertainties from the biosphere fluxes. The fossil fuel uncertainties would become more important if we increased our network design resolution.

The combined $\mathrm{CO}_{2}$ prior flux uncertainties for all four seasons are shown in Fig. 1. The additional two seasons, not used in Ziehn et al. (2014), have larger prior uncertainty contributions from the terrestrial biosphere, with maximum values in Queensland in April and in south-eastern Australia in October.

\subsection{2 $\mathrm{CH}_{4}$ prior flux uncertainties}

Prior $\mathrm{CH}_{4}$ flux uncertainties are assumed to be proportional to estimated $\mathrm{CH}_{4}$ fluxes. Total $\mathrm{CH}_{4}$ emissions are taken from the Australian $\mathrm{CH}_{4}$ budget of Fraser et al. (2011). Here, we consider contributions from anthropogenic sources such as ruminant animals, coal mining, oil production and landfills as well as contributions from natural sources including wetlands, termites and coastal ocean. For each sector (except coastal ocean, which we take as uniform), we generate a simple spatial distribution of fluxes (at the network design resolution). We assume three different flux levels (high, moderate and low), with a factor of 2 between the levels. The three flux levels are than scaled in a way that they match the sector total. Although this provides only a crude approximation of the real flux distribution, it is sufficient in this case due to the fact that we assign an uncertainty of $50 \%$ to the flux values.

Emissions from wetlands vary seasonally, whereas emissions from other sectors are assumed to be constant throughout the year. Derived prior flux uncertainties for ruminant animals and the Australian total are presented in Fig. 2. All variances are multiplied by the land fraction in a similar way to $\mathrm{CO}_{2}$ (Ziehn et al., 2014); however variances for coastal ocean fluxes are multiplied with the ocean fractions instead, and variances for fluxes from oil production are not multiplied by land or ocean fractions because we consider contributions from both offshore and onshore.

The largest anthropogenic source of $\mathrm{CH}_{4}$ in Australia is due to enteric fermentation from ruminant animals, accounting for about $2.1 \mathrm{TgC} \mathrm{yr}^{-1}$. Here we include emissions from the dairy and beef industry and from sheep grazing (ABS, 2005; MLA, 2011a, b). Fluxes are assigned based on the distribution and density of animals, with the largest concentration to be found in New South Wales (NSW), Queensland (QLD) and Victoria (VIC). In order 


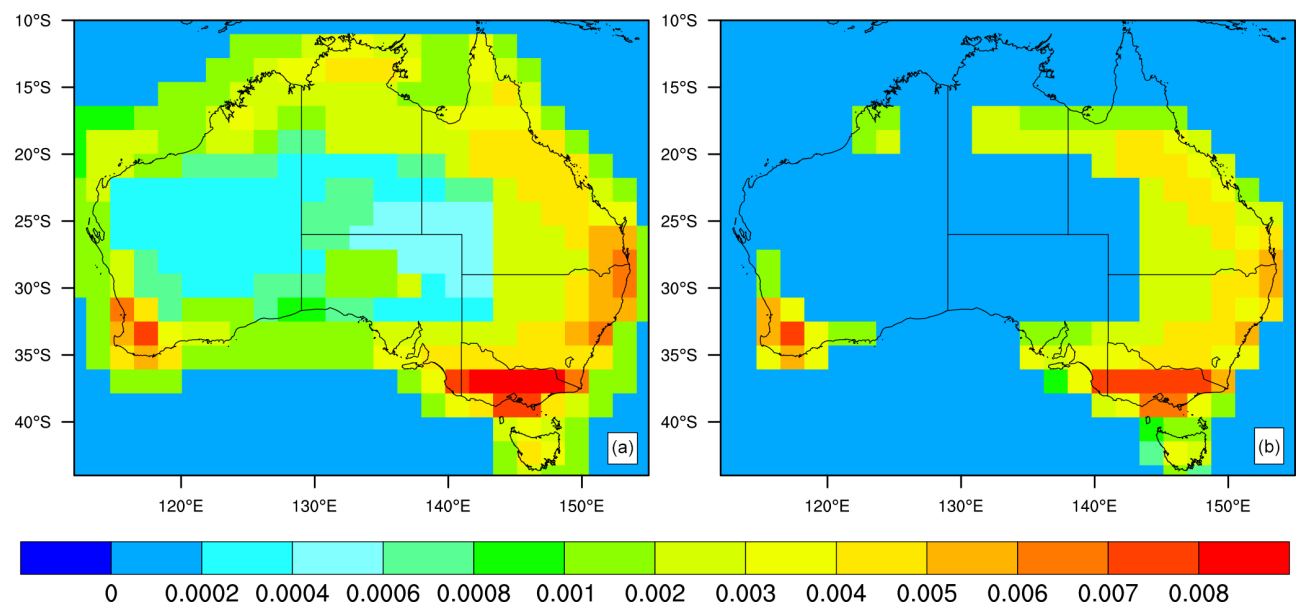

Figure 2. Prior $\mathrm{CH}_{4}$ flux uncertainties (1 standard deviation) in grams carbon per square metre per week at $1.8^{\circ}$ resolution for (a) the total and (b) ruminant land animals only. The seasonality of the wetland fluxes is not shown here in the total.

to match the sector total for ruminant animals, we assign a high flux of about $0.016 \mathrm{gCm}^{-2}$ week $^{-1}$, a medium flux of about $0.008 \mathrm{gC} \mathrm{m}^{-2}$ week $^{-1}$ and a low flux of about $0.004 \mathrm{gC} \mathrm{m}^{-2}$ week ${ }^{-1}$, with $50 \%$ of theses values used as prior flux uncertainties (Fig. 2b). All other sectors are treated in a similar way.

Coal mining accounts for about $0.6 \mathrm{TgC} \mathrm{yr}^{-1}$, with the largest density of coal mines found in NSW and QLD (GA, 2012). Emissions from oil production sum up to about $0.5 \mathrm{TgC} \mathrm{yr}^{-1}$. The majority of the oil basins are located offshore along the coast of Western Australia (WA) and VIC (GA, 2010). Landfills also contribute by about $0.5 \mathrm{TgC} \mathrm{yr}^{-1}$ and are spread out across the continent, with the highest concentration near populated areas (DOE, 2013).

Wetlands are one of the largest natural sources of $\mathrm{CH}_{4}$ in Australia, with a flux of about $1.1 \mathrm{TgC} \mathrm{yr}^{-1}$. Emissions depend mainly on temperature and groundwater (Bloom et al., 2010), and the tropical north of Australia shows a strong seasonality, with highest emissions during the wet season and soon after (December-May) (Fraser et al., 2011). Wetlands in the south of Australia show a peak in emissions during springtime (October-November) with a minimum during late autumn and winter (Bloom et al., 2012; Loh et al., 2015). The spatial distribution of the wetland $\mathrm{CH}_{4}$ fluxes used in this study is based on Australian annual mean rainfall with a seasonality as described above. Emissions from coastal oceans surrounding Australia are estimated to be about $1.1 \mathrm{TgC} \mathrm{yr}^{-1}$. Termites contribute about $1.0 \mathrm{TgC} \mathrm{yr}^{-1}$ and are present throughout Australia. The largest contribution however comes from the tropical north. Emissions from termites are not well characterised, which results in large uncertainties (Fraser et al., 2011).

\subsection{3 $\mathrm{N}_{2} \mathrm{O}$ prior flux uncertainties}

We derive prior uncertainties for $\mathrm{N}_{2} \mathrm{O}$ fluxes based on emissions from agriculture. In Australia, almost $80 \%$ of $\mathrm{N}_{2} \mathrm{O}$ is emitted from agricultural land, accounting for about $60 \mathrm{ktNyr}^{-1}$ (Dalal et al., 2003). The total annual flux is distributed across Australia at the network design resolution using three different levels (as for $\mathrm{CH}_{4}$ ) based on Australia's land uses (DOA, 2006). We assign larger fluxes to irrigated areas, because $\mathrm{N}_{2} \mathrm{O}$ emissions are generally higher from poorly drained soils and irrigation tends to increase the chance of the soils becoming waterlogged (Dalal et al., 2003). Finally, we assign the prior flux uncertainties of $\mathrm{N}_{2} \mathrm{O}$ to be $50 \%$ of the flux value as shown in Fig. 3a.

\subsection{Observational uncertainties}

Observational uncertainties include measurement, transport and aggregation errors, and if not stated otherwise we assume the same uncertainties for all existing and potential measurement stations. In the standard case, we set the observational uncertainties to $2 \mathrm{ppm}$ for $\mathrm{CO}_{2}$, to $4 \mathrm{ppb}$ for $\mathrm{CH}_{4}$ and to $0.1 \mathrm{ppb}$ for $\mathrm{N}_{2} \mathrm{O}$.

\section{Set-up and data}

The network design for Australia is performed at $1.8^{\circ} \times 1.8^{\circ}$ grid resolution by running LPDM in backward mode for stations that we would like to include in this study. Each station is assessed in terms of its ability to reduce the uncertainty on $\mathrm{CO}_{2}, \mathrm{CH}_{4}$ and $\mathrm{N}_{2} \mathrm{O}$ flux estimates. Incremental optimisation is used to find the station for which our cost function (Sect. 3.1) is minimal. This station is then removed from the candidate list (Sect. 3.2), and we repeat the incremental optimisation until the final size of the new network is reached. 
Table 1. Location of existing greenhouse gas measurement stations in Australia. Stations that are currently operational and have been selected for the base network are highlighted in bold typeface. The factor $a_{\mathrm{obs}}$ is used to scale the observational uncertainties for $\mathrm{CO}_{2}, \mathrm{CH}_{4}$ and $\mathrm{N}_{2} \mathrm{O}$ in a sensitivity experiment. For Cape Grim and Gunn Point $a_{\mathrm{obs}}$ is used in all experiments.

\begin{tabular}{llclll}
\hline No. & Station & $\begin{array}{c}\text { Location } \\
\text { lat, lon }\end{array}$ & Operation period & $\begin{array}{l}\text { Measurements } \\
\text { in situ }\end{array}$ & $a_{\text {obs }}$ \\
\hline 1 & Arcturus & $-23.86,148.47$ & $2010-2014$ & $\mathrm{CO}_{2}, \mathrm{CH}_{4}$ & $2,1,1$ \\
2 & Aspendale & $-38.01,145.01$ & 2003 -present & $\mathrm{CO}_{2}, \mathrm{CH}_{4}$ & $2,2,2$ \\
3 & Cape Ferguson & $-19.30,147.10$ & 1991 -present & - & $2,1,1$ \\
$\mathbf{4}$ & Cape Grim & $-40.70,144.70$ & 1976 -present & $\mathrm{CO}_{2}, \mathrm{CH}_{4}, \mathrm{~N}_{2} \mathrm{O}$ & $0.5,0.5,0.5$ \\
5 & Darwin & $-12.42,130.89$ & 2005 -present & $\mathrm{CO}_{2}, \mathrm{CH}_{4}, \mathrm{~N}_{2} \mathrm{O}$ & $1,1,1$ \\
$\mathbf{6}$ & Gunn Point & $-12.20,131.00$ & 2011 -present & $\mathrm{CO}_{2}, \mathrm{CH}_{4}, \mathrm{~N}_{2} \mathrm{O}$ & $0.75,0.75,0.75$ \\
7 & Otway & $-38.31,142.49$ & $2005-2012$ & $\mathrm{CO}_{2}, \mathrm{CH}_{4}$ & $1,1,1$ \\
8 & Tumbarumba & $-35.39,148.09$ & $2004-2008$ & $\mathrm{CO}_{2}$ & $2,1,1$ \\
9 & Wollongong & $-34.41,150.88$ & $2008-$-present & $\mathrm{CO}_{2}, \mathrm{CH}_{4}, \mathrm{~N}_{2} \mathrm{O}$ & $1,1,1$ \\
\hline
\end{tabular}

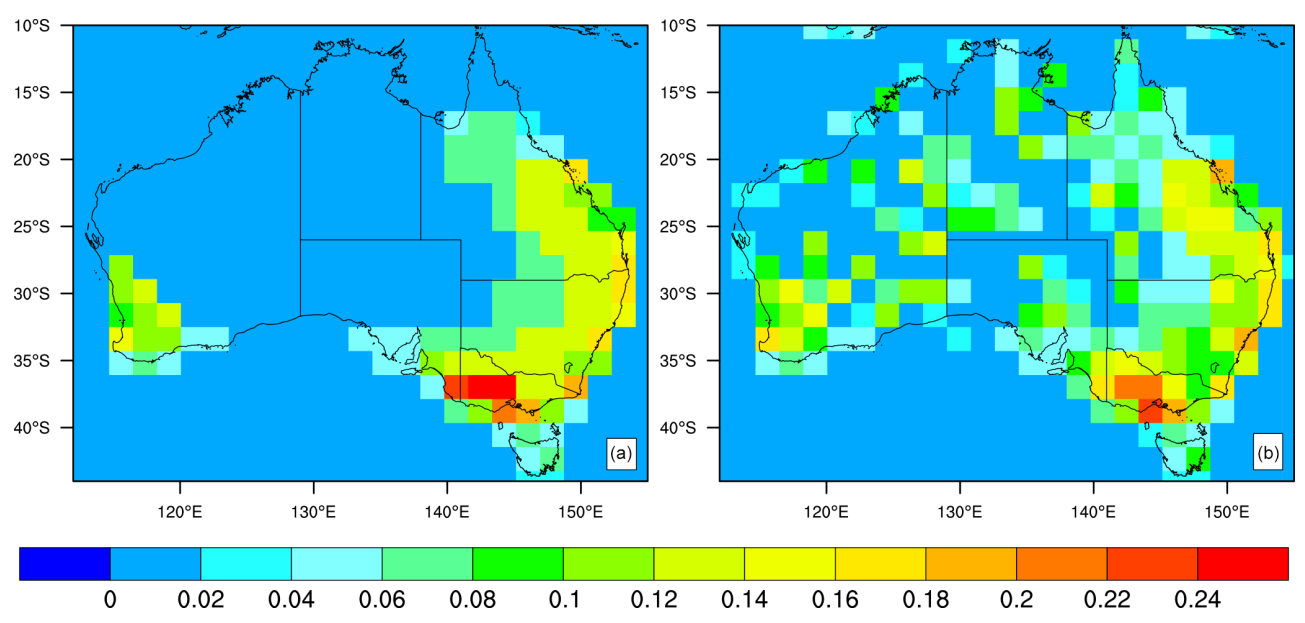

Figure 3. Prior $\mathrm{N}_{2} \mathrm{O}$ flux uncertainties ( 1 standard deviation) in milligrams nitrogen per square metre per week at $1.8^{\circ}$ resolution for (a) the total (agriculture). The random variation in flux uncertainties used for the sensitivity test is shown in (b).

In this study we add a maximum of five new stations to the base network.

\subsection{Cost function for network design}

The aim of the network design is to reduce the uncertainties on GHG flux estimates by minimising a cost function. In order to do this, we require a scalar quantity, which we obtain from the posterior covariance matrix by summing over all elements (uncertainty of the integrated flux). The cost function $J$ is then defined as

$J=\sqrt{\sum_{i=1}^{n} \sum_{j=1}^{n} C_{f_{\mathrm{ij}}}}$,

where $n$ is the number of elements in the diagonal of the matrix $\mathbf{C}_{f}$ which covers all four seasons.

We apply incremental optimisation to minimise $J$ and design observational networks for each of the three GHGs individually. The design of an optimal network which considers all three GHGs together at the same time requires a multiobjective optimisation approach. The simplest way of solv- ing a multi-objective problem is to combine its multiple objectives into a single-objective scalar function, which is also known as a weighted sum. The advantage of this approach is that we can still use the incremental optimisation method. However, a significant drawback is that we need to choose appropriate weights for each of the objectives, which can be challenging.

The new cost function $J_{\mathrm{m}}$ that combines multi-objectives is defined as

$$
J_{\mathrm{m}}=\sqrt{\left(J_{\mathrm{CO}_{2}} w_{\mathrm{CO}_{2}}\right)^{2}+\left(J_{\mathrm{CH}_{4}} w_{\mathrm{CH}_{4}}\right)^{2}+\left(J_{\mathrm{N}_{2} \mathrm{O}} w_{\mathrm{N}_{2} \mathrm{O}}\right)^{2}},
$$

where $J_{\mathrm{CO}_{2}}, J_{\mathrm{CH}_{4}}$ and $J_{\mathrm{N}_{2} \mathrm{O}}$ are the objective cost functions for the three GHGs, $\mathrm{CO}_{2}, \mathrm{CH}_{4}$ and $\mathrm{N}_{2} \mathrm{O}$ respectively. We use the global-warming potential (GWP) for a 100-year time horizon as the weight for each $\mathrm{GHG}$, i.e. $w_{\mathrm{CO}_{2}}=1, w_{\mathrm{CH}_{4}}=$ 34 and $w_{\mathrm{N}_{2} \mathrm{O}}=298$ (Myhre et al., 2013).

The performance of each network is evaluated in terms of the uncertainty reduction $U_{\mathrm{R}}$ we achieve, with $U_{\mathrm{R}}$ defined as

$U_{\mathrm{R}}=1-\frac{\hat{J}}{J^{*}} \cdot 100 \%$, 

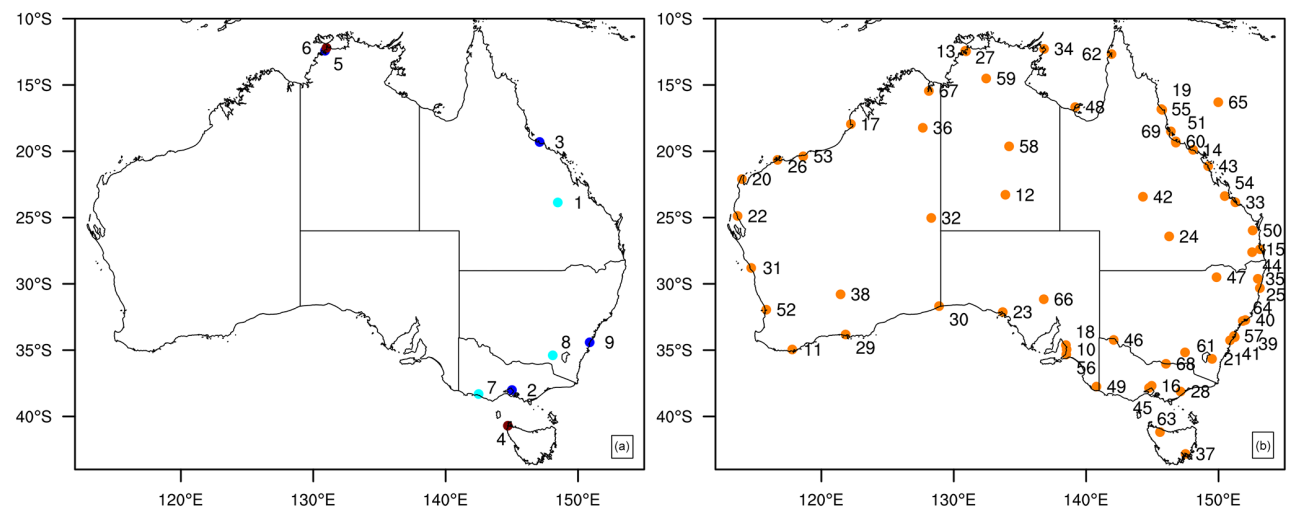

Figure 4. Location of the existing GHG measurement stations in Australia (a) and potential sites using mainly the location of the stations in the Bureau of Meteorology's National Radar Loop (b). Station names are provided in Table 1 for existing sites and Table 2 for potential sites. In (a) existing stations that are included in the base network are marked in brown, and stations that are no longer operational are marked in light blue.

where $\hat{J}$ is the optimal cost function value and $J^{*}$ is the cost function values based on the prior uncertainties.

\subsection{Existing network and potential stations}

Although Australia already commands a network of nine ground-based measurement stations as listed in Table 1 with their locations shown in Fig. 4a, only six of them are currently operational. For the base network we further select two of those six stations, located at Cape Grim and Gunn Point, for the following reasons: (1) both stations are part of the WMO/GAW global monitoring network and the Southeast Asia-Australian regional network. (2) Both stations are managed by the Australian Bureau of Meteorology (BoM), with the Commonwealth Scientific and Industrial Research Organisation (CSIRO) providing GHG research strategy. (3) Both stations provide in situ measurements for $\mathrm{CO}_{2}, \mathrm{CH}_{4}$ and $\mathrm{N}_{2} \mathrm{O}$.

For the network design, we introduce a scaling factor $a_{\text {obs }}$ in order to distinguish between the difference in quality of observations we expect to obtain from different sites. For example, for Cape Grim we set $a_{\text {obs }}$ to 0.5 , which means that we halve the observational uncertainties for $\mathrm{CO}_{2}, \mathrm{CH}_{4}$ and $\mathrm{N}_{2} \mathrm{O}$ in comparison to what we assume in the standard case (see Sect. 2.3). Similarly, for Gunn Point we choose $a_{\mathrm{obs}}=0.75$ to reflect the high accuracy of observation we expect from this station. The reason why we choose a slightly larger observational uncertainty for Gunn Point is that Gunn Point has only been operational since 2011 with a sampling height of $40 \mathrm{~m}$, which might lead to noisier records. Cape Grim, on the other hand, is our primary ground-based observing station in Australia, with data records from 1976 and a sampling height of $70 \mathrm{~m}$. For all other existing stations $a_{\mathrm{obs}}$ is set to 1 .

There are many ways of setting up a list of potential stations that one would like to include in the network design process. Commonly those stations are assigned according to a regular grid that covers the whole modelling domain. Depending on the resolution chosen, one might end up with a large list of stations that need to be assessed. Many of these potential stations might be located in inaccessible areas where it would be impossible to set up and maintain a new measurement site. Therefore, it is more beneficial to pre-select potential station locations according to a certain criterion, for example, by making use of existing infrastructure.

Here, we use mainly the locations of the Australian BoM weather watch radar stations (NRL, 2014) as potential stations. This guarantees that all stations are accessible by road, have power available and are maintained. The list of all 59 BoM stations can be found in Table 2, with their location shown in Fig. 4b. We also include one additional potential station, the Lucinda Jetty Coastal Observatory, which is currently used to collect optical data on the coastal waters and the atmosphere.

\subsection{Sensitivity tests}

The sensitivity of the network design to certain parameters used to obtain the source-receptor relationship and choices in the set-up of the network design and their consequences on the results has already been investigated by Nickless et al. (2015). Here, we focus on five different sensitivity tests, which are related to the weights assigned in the cost function for the multi-objective optimisation and the importance of prior flux uncertainties and observational uncertainties on the outcome of the network design.

SE1 In the first sensitivity test we choose a different set of weights (different to the GWP weights) in the cost function $J_{\mathrm{m}}$ such that each single objective contributes equally to the multi-objective problem, i.e. by normalising with the prior cost function values $J^{*}$ using $w_{\mathrm{CO}_{2}}=$ $1 / J_{\mathrm{CO}_{2}}^{*}, w_{\mathrm{CH}_{4}}=1 / J_{\mathrm{CH}_{4}}^{*}$ and $w_{\mathrm{N}_{2} \mathrm{O}}=1 / J_{\mathrm{N}_{2} \mathrm{O}}^{*}$. In this 
Table 2. Location of potential greenhouse gas measurement stations using the location of the Bureau of Meteorology weather watch radar stations including one additional station at Lucinda Jetty. The factor $a_{\mathrm{obs}}$ is used to scale the observational uncertainties for $\mathrm{CO}_{2}$, $\mathrm{CH}_{4}$ and $\mathrm{N}_{2} \mathrm{O}$ in a sensitivity experiment.

\begin{tabular}{|c|c|c|c|c|c|c|c|}
\hline No. & Station & $\begin{array}{l}\text { Location } \\
\text { lat, lon }\end{array}$ & $a_{\mathrm{obs}}$ & No. & Station & $\begin{array}{l}\text { Location } \\
\text { lat, lon }\end{array}$ & $a_{\mathrm{obs}}$ \\
\hline 10 & Adelaide Airport & $-34.95,138.53$ & $2,1,1$ & 40 & Lemon Tree Pass & $-32.73,152.03$ & $2,1,1$ \\
\hline 11 & Albany & $-34.95,117.80$ & $1,1,1$ & 41 & Letterbox & $-34.26,150.87$ & $1,1,1$ \\
\hline 12 & Alice Springs & $-23.82,133.90$ & $1,1,1$ & 42 & Longreach & $-23.43,144.29$ & $2,1,1$ \\
\hline 13 & Berrimah & $-12.46,130.93$ & $1,1,1$ & 43 & Mackay & $-21.12,149.22$ & $2,1,1$ \\
\hline 14 & Bowen & $-19.87,148.08$ & $2,1,1$ & 44 & Marburg & $-27.61,152.54$ & $1,2,1$ \\
\hline 15 & Brisbane Airport & $-27.39,153.13$ & $1,2,1$ & 45 & Melbourne Laverton & $-37.85,144.75$ & $2,2,2$ \\
\hline 16 & Broadmeadows & $-37.69,144.95$ & $2,2,2$ & 46 & Mildura & $-34.23,142.08$ & $1,1,1$ \\
\hline 17 & Broome & $-17.95,122.23$ & $1,1,1$ & 47 & Moree & $-29.50,149.85$ & $2,1,1$ \\
\hline 18 & Buckland Park & $-34.62,138.57$ & $2,1,1$ & 48 & Mornington Island & $-16.67,139.17$ & $1,1,1$ \\
\hline 19 & Cairns Airport & $-16.88,145.75$ & $1,1,1$ & 49 & Mt. Gambier & $-37.75,140.78$ & $1,1,1$ \\
\hline 20 & Cape Range & $-22.10,114.00$ & $1,1,1$ & 50 & Mt. Kanighan & $-25.97,152.58$ & $1,1,1$ \\
\hline 21 & Captains Flat & $-35.66,149.51$ & $1,2,2$ & 51 & Mt. Stuart & $-19.35,146.78$ & $1,1,1$ \\
\hline 22 & Canarvon & $-24.88,113.67$ & $1,1,1$ & 52 & Perth & $-31.95,115.84$ & $2,2,1$ \\
\hline 23 & Ceduna & $-32.13,133.70$ & $1,1,1$ & 53 & Port Hedland & $-20.38,118.63$ & $1,1,1$ \\
\hline 24 & Charleville & $-26.42,146.27$ & $2,1,1$ & 54 & Rockhampton & $-23.38,150.47$ & $2,1,1$ \\
\hline 25 & Coffs Harbour & $-30.32,153.12$ & $1,2,1$ & 55 & Saddle Mtn & $-16.82,145.68$ & $1,1,1$ \\
\hline 26 & Dampier & $-20.65,116.69$ & $1,1,1$ & 56 & Sellicks Hill & $-35.33,138.50$ & $2,1,1$ \\
\hline 27 & Darwin Airport & $-12.42,130.87$ & $1,1,1$ & 57 & Sydney Airport & $-33.93,151.17$ & $2,2,1$ \\
\hline 28 & East Sale & $-38.12,147.13$ & $1,2,1$ & 58 & Tennant Creek & $-19.63,134.18$ & $1,1,1$ \\
\hline 29 & Esperance & $-33.82,121.83$ & $1,1,1$ & 59 & Tindal & $-14.51,132.45$ & $1,1,1$ \\
\hline 30 & Eucla & $-31.68,128.89$ & $1,1,1$ & 60 & Townsville & $-19.25,146.77$ & $2,1,1$ \\
\hline 31 & Geraldton & $-28.80,114.70$ & $1,1,1$ & 61 & Wagga & $-35.17,147.47$ & $2,1,1$ \\
\hline 32 & Giles & $-25.03,128.30$ & $1,1,1$ & 62 & Weipa & $-12.67,141.92$ & $1,1,1$ \\
\hline 33 & Gladstone & $-23.85,151.27$ & $2,1,1$ & 63 & West Takone & $-41.18,145.58$ & $1,1,1$ \\
\hline 34 & Gove & $-12.28,136.82$ & $1,1,1$ & 64 & Williamtown & $-32.80,151.83$ & $2,1,1$ \\
\hline 35 & Grafton & $-29.62,152.97$ & $1,2,1$ & 65 & Willis Island & $-16.30,149.98$ & $1,1,1$ \\
\hline 36 & Halls Creek & $-18.23,127.66$ & $1,1,1$ & 66 & Woomera & $-31.16,136.80$ & $1,1,1$ \\
\hline 37 & Hobart Airport & $-42.83,147.51$ & $1,1,1$ & 67 & Wyndham & $-15.45,128.12$ & $1,1,1$ \\
\hline 38 & Kalgoorlie & $-30.79,121.45$ & $1,1,1$ & 68 & Yarrawonga & $-36.03,146.03$ & $2,2,1$ \\
\hline 39 & Kurnell & $-34.02,151.23$ & $2,2,1$ & 69 & Lucinda Jetty & $-18.50,146.40$ & $1,1,1$ \\
\hline
\end{tabular}

way we ensure that no priority is given to a GHG with larger prior flux uncertainty values.

SE2 The second sensitivity test focuses on the way we assign observational uncertainties for stations not in the base network. Rather than use the same uncertainty for all potential stations, we double the uncertainty for sites close to large GHG sources $\left(a_{\mathrm{obs}}=2\right)$. The assumption is that sites close to large sources will have "noisier" measurements and may be more difficult to model, and this should be accounted for by a larger observational uncertainty.

We test the impact of the increased uncertainties on the network design. The scaling factor $a_{\text {obs }}$ that we use for this sensitivity test is provided in Tables 1 and 2 for each of the stations and GHGs investigated here.

SE3 In a third sensitivity experiment we look at the impact of the way we derive the prior flux uncertainties for $\mathrm{CH}_{4}$ and $\mathrm{N}_{2} \mathrm{O}$. In contrast to the prior flux uncertainties for $\mathrm{CO}_{2}$ which are derived from high-resolution model simulations with daily output, the prior flux uncertainties for $\mathrm{CH}_{4}$ and $\mathrm{N}_{2} \mathrm{O}$ are based an annual budgets with a spatial distribution generated using density maps from various sectors as described in Sect. 2.2. We acknowledge that the spatial pattern and the magnitude of the flux components we derive in this way are to some degree arbitrary. In order to test the impact of our prior flux uncertainties for $\mathrm{CH}_{4}$ and $\mathrm{N}_{2} \mathrm{O}$ on the network design results, we randomly vary assigned fluxes for each sector in the following way: (a) if a grid cell already has a flux assigned, we randomly vary the current flux by a maximum of $\pm 25 \%$, and (b) if a grid cell has a zero flux, we give that grid cell a $50 \%$ chance of a flux at a moderate level. Flux uncertainties are then derived as before by using $50 \%$ of the assigned flux value.

SE4 Although the focus of this study is not on minimising exact economic costs associated with setting up and maintaining a new station, in the fourth sensitivity experiment we include the distance $d$ from Aspendale (as the location of the base laboratory from which a network could be run) to any other existing or potential station by adding the following term to the cost function:

$J_{\mathrm{md}}=J_{m}+\frac{d}{\max (d)} w_{\mathrm{d}}$ 
The distance to a remote site is a possible factor in the maintenance costs for a site, assuming service visits require staff to travel from the base laboratory. We also introduce a weight factor $w_{\mathrm{d}}$ to scale the overall importance of the distance in the cost function.

SE5 In a final sensitivity test we combine SE2 and SE4 to consider increased observational uncertainties together with distance for the combined optimisation using GWP weights in the cost function.

\section{Results and discussion}

\subsection{Base network}

Our base network consists of only two stations, Cape Grim and Gunn Point. However, observations from those two stations are already able to significantly reduce the uncertainties on GHG flux estimates for Australia as shown in Table 3. Gunn Point is the most important station in terms of its ability to reduce uncertainties on $\mathrm{CO}_{2}$ flux estimates (about $11 \%$ ), whereas Cape Grim is the most important station in terms of its ability to reduce uncertainties on $\mathrm{CH}_{4}$ and $\mathrm{N}_{2} \mathrm{O}$ flux estimates (about 8 and $10 \%$ respectively). Overall, both stations together are able to reduce the uncertainties on all three GHG flux estimates between 12 and $17 \%$.

\subsection{Extended networks}

We first design optimal network extensions for each GHG individually by adding up to five new stations to the base network using incremental optimisation as described earlier. The ranking of the new stations is presented in Table 4, with their uncertainty reduction shown in Fig. 5a and their location shown in Fig. 6a.

The $\mathrm{CO}_{2}$ network extension is similar to the one derived in Ziehn et al. (2014), despite using a different base network (two instead of six stations) and using all four seasons (instead of only two seasons) as driving data. The first station that is added to the base network is located at Charleville, which is the only station that was not included in the network derived in Ziehn et al. (2014). This is mainly driven by the large prior biosphere flux uncertainties in April in the eastern part of the Australian continent (see Fig. 1b). The other four stations added to the network are identical to the ones selected in Ziehn et al. (2014). The new optimal $\mathrm{CO}_{2}$ observing network is able to reduce the $\mathrm{CO}_{2}$ flux uncertainties by about $47 \%$ and consists of three stations in the tropical north (Gunn Point, Wyndham and Mornington Island), two stations in eastern Australia (Charleville and Moree) and two stations in the south-east of Australia (Cape Grim and Tumbarumba).

The network extension focussing on $\mathrm{CH}_{4}$ only is similar to the optimal $\mathrm{CO}_{2}$ network extension due to a similar distribution of prior flux uncertainties, at least for the eastern part
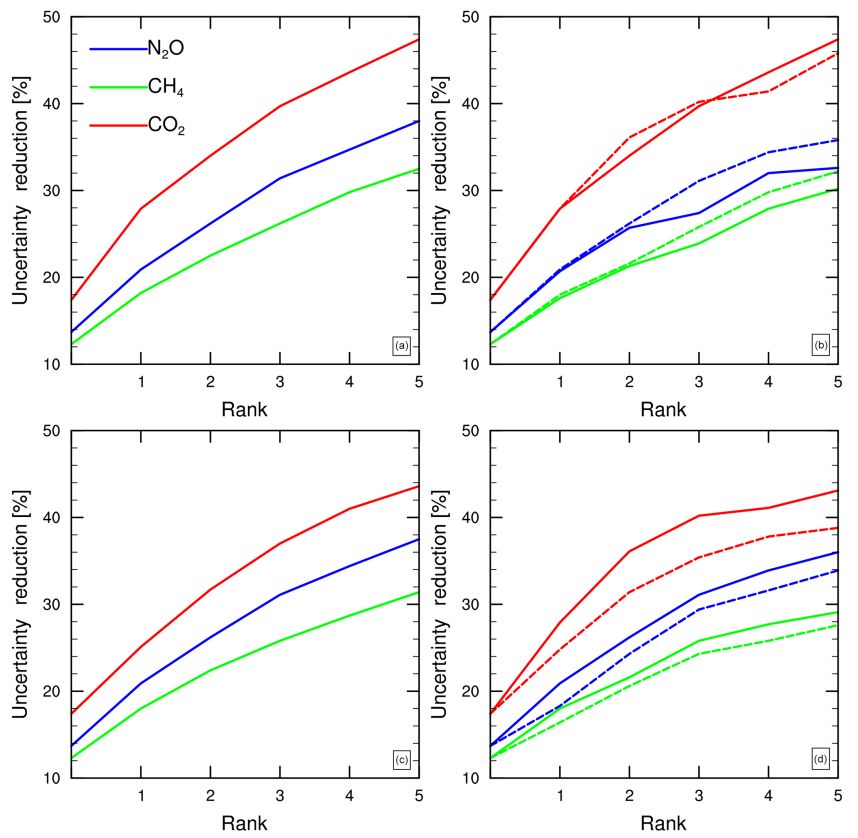

Figure 5. Uncertainty reduction for the five stations added to the base network for (a) each GHG individually, (b) the multi-objective optimisation (solid lines: GWP weights; dashed lines: equal weights (SE1)), (c) the sensitivity test (SE2) with changed observational uncertainties for each GHG individually and (d) the sensitivity test (SE4) with multi-objective optimisation using GWP weights that also includes the distance (solid lines) and SE5 (dashed lines) (red: $\mathrm{CO}_{2}$; green: $\mathrm{CH}_{4}$; and blue: $\mathrm{N}_{2} \mathrm{O}$ ).

of the Australian continent. Tumbarumba becomes the most important station in the $\mathrm{CH}_{4}$ network extension, and, as in the $\mathrm{CO}_{2}$ case, Moree is the second-most-important location. However, the optimisation also places a station in Perth on the west coast of Australia, which was not required for $\mathrm{CO}_{2}$. In total we are able to achieve a reduction of about $32 \%$ on $\mathrm{CH}_{4}$ flux uncertainties.

The optimal $\mathrm{N}_{2} \mathrm{O}$ network shows some similarities with the optimal $\mathrm{CO}_{2}$ and $\mathrm{CH}_{4}$ network. Moree is added first by the optimisation, which highlights the importance of this location for all three GHGs. Three stations in the $\mathrm{N}_{2} \mathrm{O}$ observing network are located in the south-east (Cape Grim, Broadmeadows and Captains Flat), which is the region where we also assume the largest prior flux uncertainties. The new $\mathrm{N}_{2} \mathrm{O}$ network is able to reduce the $\mathrm{N}_{2} \mathrm{O}$ flux uncertainties by about $38 \%$.

We now use the cost function that combines multiobjectives (Eq. 7) to design a network that is optimal for all three GHGs combined. Although the ranking of the stations shown in Table 4 is for the combined network; the uncertainty reduction is calculated for each GHG individually (Fig. 5b) to make it comparable with the previous networks. From the ranking of the stations in Table 4 we can see that the optimal combined network is exactly the same as the op- 
Table 3. Uncertainty reduction $\left(U_{\mathrm{R}}\right)$ for the two existing stations in the base network in terms of their ability to reduce the uncertainties on $\mathrm{CO}_{2}, \mathrm{CH}_{4}$ and $\mathrm{N}_{2} \mathrm{O}$ flux estimates. The station number is provided in brackets.

\begin{tabular}{lrrr}
\hline Station (No.) & $U_{\mathrm{R}} \mathrm{CO}_{2}$ & $U_{\mathrm{R}} \mathrm{CH}_{4}$ & $U_{\mathrm{R}} \mathrm{N}_{2} \mathrm{O}$ \\
\hline Cape Grim (4) & $7.1 \%$ & $8.4 \%$ & $10.4 \%$ \\
Gunn Point (6) & $11.3 \%$ & $4.1 \%$ & $3.9 \%$ \\
Cape Grim (4) + Gunn Point (6) & $17.4 \%$ & $12.3 \%$ & $13.7 \%$ \\
\hline
\end{tabular}

Table 4. Ranking for new stations added to the base network in terms of their ability to reduce the uncertainties on $\mathrm{CO}_{2}, \mathrm{CH}_{4}$ and $\mathrm{N}_{2} \mathrm{O}$ flux estimates individually and in combination (using GWP weights in cost function). The station number is provided in brackets.

\begin{tabular}{lllll}
\hline Rank & $\mathrm{CO}_{2}$ stations & $\mathrm{CH}_{4}$ stations & $\mathrm{N}_{2} \mathrm{O}$ stations & Combined GWP \\
\hline 1 & Charleville (24) & Tumbarumba (8) & Moree (47) & Charleville (24) \\
2 & Moree (47) & Moree (47) & Longreach (42) & Moree (47) \\
3 & Mornington Island (48) & Perth (52) & Captains Flat (21) & Mornington Island (48) \\
4 & Tumbarumba (8) & Longreach (42) & Perth (52) & Tumbarumba (8) \\
5 & Wyndham (67) & Wyndham (67) & Broadmeadows (16) & Wyndham (67) \\
\hline
\end{tabular}

timal $\mathrm{CO}_{2}$-only network. This is due to the way the weights are assigned for the contributions of all three GHGs (according to the GWP); priority is given to the reduction of $\mathrm{CO}_{2}$ flux uncertainties, because the prior $\mathrm{CO}_{2}$ fluxes have by far the largest uncertainties. For example, the $\mathrm{CO}_{2}$ prior flux uncertainties are by about 3 orders of magnitude larger than the $\mathrm{CH}_{4}$ prior flux uncertainties (Figs. 1 and 2 ).

Given that the optimal combined network is the same as the optimal $\mathrm{CO}_{2}$ network, the reduction in uncertainty for $\mathrm{CO}_{2}$ is unchanged. For $\mathrm{CH}_{4}$ and $\mathrm{N}_{2} \mathrm{O}$ uncertainty reductions are 30 and $33 \%$ respectively, only 2 and $5 \%$ less than for the individual networks.

\subsection{Sensitivity tests}

Sensitivity test SE1 changes the weights in the cost function $J_{\mathrm{m}}$ so that each single objective for the three GHGs contributes equally to $J_{\mathrm{m}}$ (Sect. 3.3) despite the order-ofmagnitude difference in the prior flux uncertainty values for each of the three GHGs (Figs. 1-3). Table 5 and Fig. 6b indicate that the network based on equal weights is somewhat different to the network based on GWP weights. Moree, Tumbarumba and Mornington Island appear in both networks, but the network based on equal contributions now includes Perth (instead of Wyndham) and Longreach (instead of Charleville,) which are stations that were only included in the $\mathrm{CH}_{4}$ and $\mathrm{N}_{2} \mathrm{O}$ networks (Table 4). In particular, a station in Perth does not significantly contribute to a reduction in $\mathrm{CO}_{2}$ flux uncertainties, but it is selected now that a reduction of flux uncertainties is equally important for all three GHGs. The replacement of Charleville with Longreach is only a minor change since both stations are located in roughly the same region in the east of the continent.

As expected, the SE1 network trades off decreased uncertainty reductions for $\mathrm{CO}_{2}$ with increased uncertainty reductions for $\mathrm{CH}_{4}$ and $\mathrm{N}_{2} \mathrm{O}$ (Fig. 5b). However the changes in uncertainty reduction are relatively small, at only $2-4 \%$ for the networks with five additional sites.

Networks for the SE2 test were optimised for each GHG individually using increased observational uncertainties for sites that are expected to be close to large fluxes. For $\mathrm{CO}_{2}$ the new network (Fig. 6c) is mostly different from the previous one since the original network contained three sites (Charleville, Moree, Tumbarumba) that we penalised for being close to large sources. All are removed from the new network, being replaced by Marburg, Captains Flat and Coffs Harbour, which are closer to the east coast. Interestingly the optimisation also chose to replace Wyndham with Tennant Creek despite Wyndham not having an increased observational uncertainty. However, in this configuration both stations provide about the same reduction in uncertainty and are therefore interchangeable. The uncertainty reduction for the SE2 $\mathrm{CO}_{2}$ network was $4 \%$ lower than for the original network (Fig. 5c).

For $\mathrm{CH}_{4}$, only one site (Perth) in the standard network was allocated an increased uncertainty, and the SE2 optimisation produces the same network, retaining Perth though adding it to the network as additional site 4 rather than site 3 in terms of the ranking. The increased observational uncertainty for Perth results in a slightly smaller flux uncertainty reduction. We also explored replacing Perth with either Geraldton or Albany, which do not have increased observational uncertainties for SE2, and this would result in a network with almost the same performance.

Large $\mathrm{N}_{2} \mathrm{O}$ sources are mainly located in the south-east of the country, and two stations (Captains Flat and Broadmeadows) from the previous optimal $\mathrm{N}_{2} \mathrm{O}$ network are allocated higher observational uncertainty in SE2. Consequently these are dropped from the new optimal $\mathrm{N}_{2} \mathrm{O}$ network, being replaced by different locations in SE Australia (Tumbarumba 
Table 5. Ranking for new stations added to the base network in terms of their ability to reduce the uncertainties on $\mathrm{CO}_{2}, \mathrm{CH}_{4}$ and $\mathrm{N}_{2} \mathrm{O}$ flux estimates for some of the sensitivity tests: SE1 - using equal contributions of the three GHGs; SE4 - using GWP weights and distance measure; and SE5 - using GWP weights, distance measure and increased observational uncertainties for stations close to large sources. The station number is provided in brackets.

\begin{tabular}{llll}
\hline Rank & Combined SE1 & Combined SE4 & Combined SE5 \\
\hline 1 & Moree (47) & Moree (47) & Letterbox (41) \\
2 & Longreach (42) & Longreach (42) & Longreach (42) \\
3 & Tumbarumba (8) & Tumbarumba (8) & Moree (47) \\
4 & Perth (52) & Broadmeadows (16) & Captains Flat (21) \\
5 & Mornington Island (48) & Williamtown (64) & East Sale (28) \\
\hline
\end{tabular}
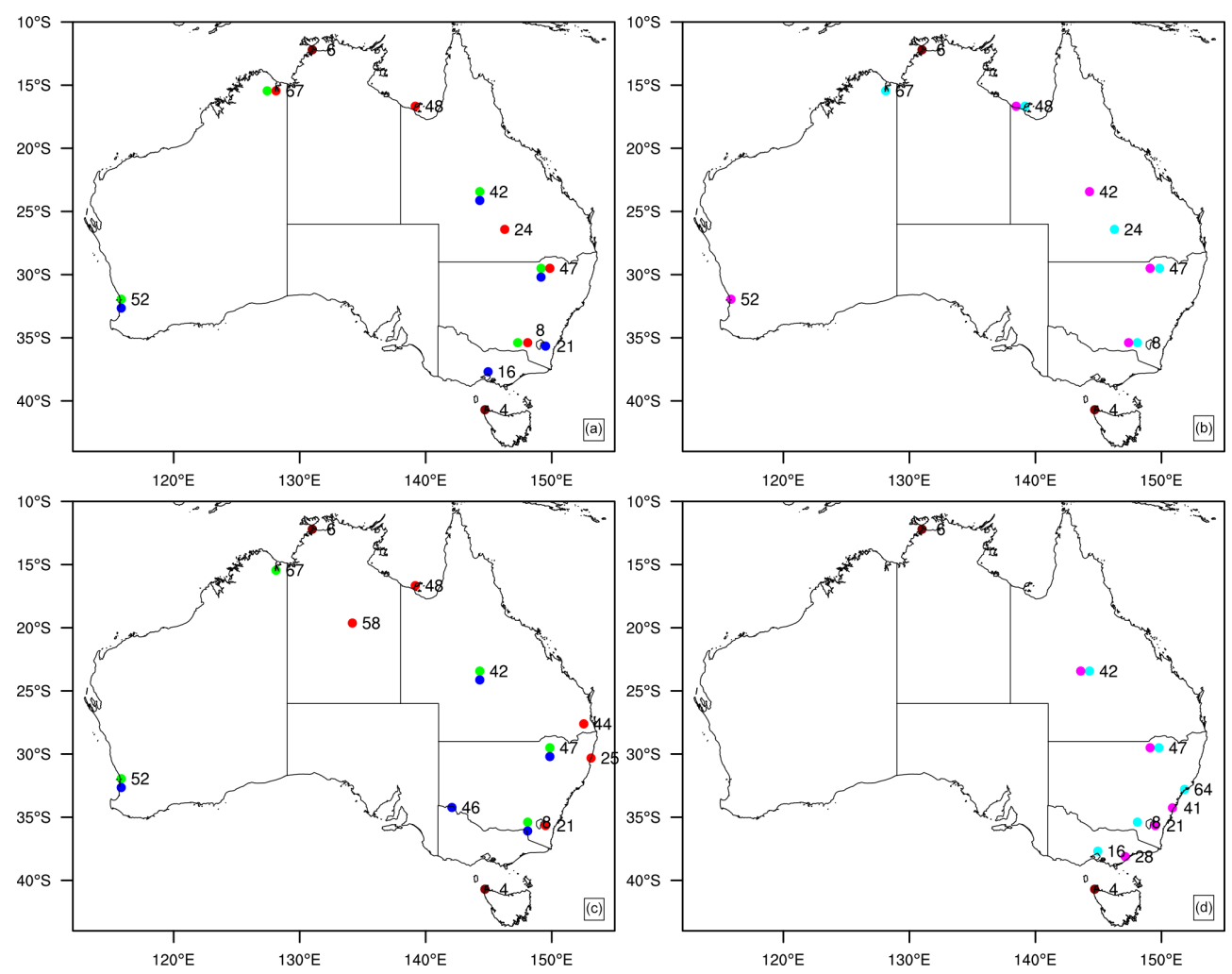

Figure 6. Location of the proposed GHG measurement stations in Australia using the network design for (a) each GHG individually (red: $\mathrm{CO}_{2}$; green: $\mathrm{CH}_{4}$; and blue: $\mathrm{N}_{2} \mathrm{O}$ ), (b) the multi-objective optimisation (light blue: GWP weights; pink: equal weights - SE1), (c) the sensitivity test (SE2) with changed observational uncertainties for each GHG individually (red: $\mathrm{CO}_{2} ;$ green: $\mathrm{CH}_{4} ;$ and blue: $\left.\mathrm{N}_{2} \mathrm{O}\right)$ and $(\mathbf{d})$ the sensitivity test (SE4) with multi-objective optimisation using GWP weights that also includes the distance (light blue) and SE5 (pink). The location of the stations in the base network is marked in brown.

and Mildura). The performance of the new network is comparable to the standard case.

SE3 assessed the impact of changing the prior $\mathrm{CH}_{4}$ and $\mathrm{N}_{2} \mathrm{O}$ flux values and their distribution, finding only a minor impact on the optimal $\mathrm{CH}_{4}$ and $\mathrm{N}_{2} \mathrm{O}$ network. For $\mathrm{CH}_{4}$, Moree, Perth and Longreach remain in the optimal network. Tumbarumba in the south-east is replaced by Captains Flat, also in the south-east, and Wyndham located in the north is replaced by Halls Creek, also located in the north but further inland. For $\mathrm{N}_{2} \mathrm{O}$ the change in flux uncertainties produces a different ranking of sites but only one change in selected sites; Broadmeadows in the south is replaced by Charleville in the east of the country. At first it seems surprising that Broadmeadows is dropped from the network, taking into account the large $\mathrm{N}_{2} \mathrm{O}$ uncertainties in Victoria. However, Cape Grim in the base network already constrains fluxes from Victoria, and the random change in prior $\mathrm{N}_{2} \mathrm{O}$ fluxes has also led to a reduction in the prior uncertainties for south-east Australia.

Sensitivity tests SE4 (standard observational uncertainties) and SE5 (observational uncertainties from SE2) included the distance of stations to Aspendale as an additional criterion 
in the cost function used for determining a combined network (with GWP weights for the three different GHGs). The sum of distances to the five stations in the original network is about $8200 \mathrm{~km}$. If we add the distance to the cost function setting $w_{\mathrm{d}}=10$, we obtain network extensions (Table 5, Figs. 5d and 6d) for both SE4 and SE5 where the sum of station distances is reduced to about $4000 \mathrm{~km}$. For SE4 the new network retains Moree and Tumbarumba, and adds Longreach and Williamtown to the network in the east of the country. The final station in the SE4 optimal network extension is Broadmeadows, which is very close to Aspendale (base laboratory). For SE5 two locations (Longreach and Moree) are the same as for SE4; the other three sites are relatively close to those selected for SE4 but are chosen in preference to the SE4 selection because their $\mathrm{CO}_{2}$ observational uncertainty is lower.

The additional distance constraint in our multi-objective problem means that we generally see a decrease in the performance of the new networks. Compared to the standard combined network, the reduction in flux uncertainty for SE4 is lower by about $4.5 \%$ for $\mathrm{CO}_{2}$ and $1 \%$ for $\mathrm{CH}_{4}$ but larger for $\mathrm{N}_{2} \mathrm{O}$ by $3.5 \%$ (Fig. 5). This is because the largest prior flux uncertainties for $\mathrm{N}_{2} \mathrm{O}$ are located in the south-east of the country, and hence $\mathrm{N}_{2} \mathrm{O}$ benefits from moving the network closer to Aspendale in SE Australia. For SE5, the reduction in flux uncertainty is further decreased for $\mathrm{CO}_{2}$ and $\mathrm{CH}_{4}$ (8.5 and $2.5 \%$ ), but still slightly larger for $\mathrm{N}_{2} \mathrm{O}$ by $1 \%$ when compared to the standard combined network.

We also varied the weights $w_{\mathrm{d}}$ in SE4 to assess the performance of the optimal network with respect to the sum of stations' distances as show in Fig. 7a. For $\mathrm{CO}_{2}$ and $\mathrm{CH}_{4}$ the performance of the network decreases relatively slowly when decreasing the stations' total distance from about $8200 \mathrm{~km}$ to about $3000 \mathrm{~km}\left(6 \%\right.$ decrease for $\mathrm{CO}_{2}$ and $3 \%$ decrease for $\mathrm{N}_{2} \mathrm{O}$ ), but it drops significantly for $\mathrm{CO}_{2}$ after that. The network performance for $\mathrm{N}_{2} \mathrm{O}$ increases by about $3 \%$ for the reasons given above before it drops at about $4000 \mathrm{~km}$.

\subsection{Limitations}

When we add more constraints to the cost function or increase the observational uncertainties for our stations, we expect that the performance of the optimal network expressed through the uncertainty reduction will be reduced. Although this is generally true for the full network extension consisting of five additional stations, we notice that, for example, by adding only two stations the performance of the $\mathrm{CO}_{2}$ only network is actually slightly worse than the performance of the combined network using equal contributions of the three GHGs in the cost function (Fig. 5a, b). This is because the incremental optimisation adds one station at a time, which maximises the performance of the network only at each stage. The incremental optimisation is not able to assess benefits that may arise by adding a number of stations at the same time, which other optimisation methods such as the
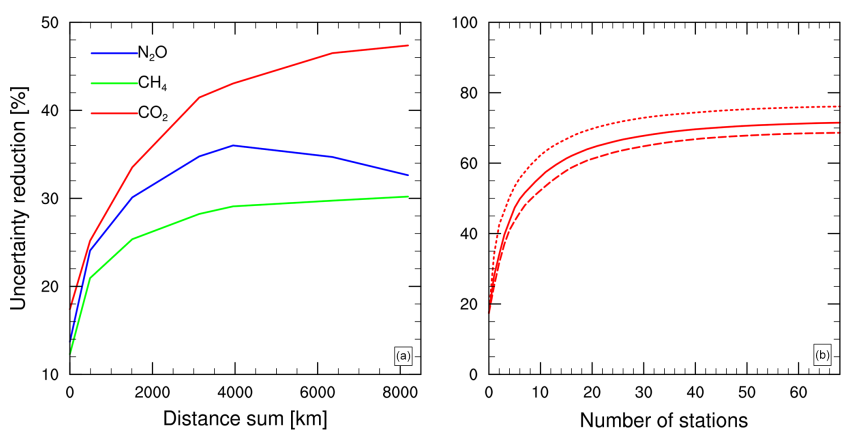

Figure 7. (a) Uncertainty reduction for the three GHGs (red: $\mathrm{CO}_{2}$; green: $\mathrm{CH}_{4}$; and blue: $\mathrm{N}_{2} \mathrm{O}$ ) with respect to the total distance to Aspendale for the five stations in the network extension and (b) uncertainty reduction for $\mathrm{CO}_{2}$ for the default case (solid line), increased observational uncertainties SE2 (dashed line) and observational uncertainty for all stations set to almost zero (dotted line).

genetic algorithm (Rayner, 2004; Lucas et al., 2014) are able to do. However, Nickless et al. (2015) found that the genetic algorithm provided only marginally better solutions when compared with the incremental optimisation, but at a much larger computational cost.

Due to the fact that we pre-select the location of new stations through a list of potential sites, we impose an initial constraint on the network design. Even if we include all potential stations in our network, we would only achieve an uncertainty reduction of about $70 \%$ for $\mathrm{CO}_{2}$ in the standard case (Fig. 7b). Lowering the observational uncertainty to almost zero for all stations only provides an additional $5 \%$ in uncertainty reduction for all stations to the network. This indicates that our network design is ultimately limited by our pre-selection of sites rather than our ability to model the GHG concentrations at those sites. Given that almost all of our optimal networks selected inland sites in eastern Australia ahead of coastal sites, this study would suggest that additional locations with existing infrastructure should be identified in inland NSW and Queensland to supplement our potential site list, which, using the BoM radar network, is biased to coastal or near-coastal locations.

\section{Summary and conclusions}

In this study we used the Bayesian framework and a Lagrangian particle dispersion model in reverse mode to design optimal GHG observing networks for Australia individually for the three GHGs and together through a combination of multi-objectives with weights assigned to each GHG. The choice of weights would depend on the network design application. Only when we chose the weights in a way that ensured that each single objective contributed equally to the multi-objective problem were we able to derive an optimal combined network that did not favour one of the three GHGs; a GWP-based weighting clearly favoured $\mathrm{CO}_{2}$. 
Due to similarities in the distribution of the prior flux uncertainties for the three GHGs, we obtained optimal individual and combined networks that showed a number of similarities, which is a positive outcome for any application of this study to investment in new sites. Most stations in the network extensions are located in the eastern part of the Australian continent (e.g. Moree and Tumbarumba), with a few stations in the north. For $\mathrm{CH}_{4}$ and $\mathrm{N}_{2} \mathrm{O}$, a site in SW Australia is also of value.

The assignment of appropriate observational uncertainties to each station was found to be critical; network selection avoided sites that were assigned a larger uncertainty, replacing them with sites further from large sources and resulting in a small penalty in the overall effectiveness of the network for reducing flux uncertainty. Future work should be directed to better characterising the observational uncertainty for different sites, particularly at the component that accounts for our ability (or inability) to model GHG concentrations at specific locations. Observations from our existing network could be used for this characterisation as they span a range of site conditions. For example, Tumbarumba, which is often selected by the network design, is a forested site which may be challenging to model. Though not currently operational, existing measurements could be used to test assumptions about observational uncertainties.

Economic costs were included in two ways. Firstly, we pre-selected potential stations to account for existing infrastructure. In fact, we only included potential stations that were already set up and maintained for other measurement purposes. This places an initial constraint on the network design, which means that even with almost no observational error we would only achieve an uncertainty reduction of $75 \%$ for $\mathrm{CO}_{2}$ with all potential stations included in our network. Secondly, we included the distance from Aspendale (location of the base laboratory) to all other stations as a measure of maintenance costs in the cost function. We demonstrated that the total distance to the additional five stations in the optimal combined network can be more than halved with only a slight decrease in the performance of the network. By changing the weights for the distance, the user can decide if the priority is on a more cost-efficient network or a network that provides the largest overall reduction in GHG flux uncertainties.

We conclude that an optimal measurement network designed for $\mathrm{CO}_{2}$ only also performs well for $\mathrm{CH}_{4}$ and $\mathrm{N}_{2} \mathrm{O}$. This is due to large similarities in the pattern of the prior flux uncertainties derived for each of the three GHGs. This might change if we are able to obtain more detailed information particularly on the $\mathrm{CH}_{4}$ and $\mathrm{N}_{2} \mathrm{O}$ flux distribution and increase the resolution so that point sources (i.e. fossil fuel emissions) become more important.
Acknowledgements. P. Rayner is in receipt of an Australian Professorial Fellowship (DP1096309).

Edited by: J. Dumoulin

\section{References}

ABS: Australia's beef cattle industry, Australian Bureau of Statistics, available at: http://www.abs.gov.au/ausstats/abs@ .nsf/Previousproducts/1301.0Feature\%20Article232005? opendocument (last access: 26 May 2015), 2005.

Asefi-Najafabady, S., Rayner, P. J., Gurney, K. R., McRobert, A., Song, Y., Coltin, K., Elvidge, C., and Baugh, K.: A multiyear, global gridded fossil fuel $\mathrm{CO}_{2}$ emission data product: Evaluation and analysis of results, J. Geophys. Res.-Atmos., 119, 1021310231, 10.1002/2013JD021296, 2014.

Bloom, A. A., Palmer, P. I., Fraser, A., Reay, D. S., and Frankenberg, C.: Large-scale controls of methanogenesis inferred from methane and gravity spaceborne data, Science, 327, 322-325, doi:10.1126/science.1175176, 2010.

Bloom, A. A., Palmer, P. I., Fraser, A., and Reay, D. S.: Seasonal variability of tropical wetland $\mathrm{CH}_{4}$ emissions: the role of the methanogen-available carbon pool, Biogeosciences, 9, 28212830, doi:10.5194/bg-9-2821-2012, 2012.

Chevallier, F., Ciais, P., Conway, T. J., Aalto, T., Anderson, B. E., Bousquet, P., Brunke, E. G., Ciattaglia, L., Esaki, Y., Fröhlich, M., Gomez, A., Gomez-Pelaez, A. J., Haszpra, L., Krummel, P. B., Langenfelds, R. L., Leuenberger, M., Machida, T., Maignan, F., Matsueda, H., Morgui, J. A., Mukai, H., Nakazawa, T., Peylin, P., Ramonet, M., Rivier, L., Sawa, Y., Schmidt, M., Steele, L. P., Vay, S. A., Vermeulen, A. T., Wofsy, S., and Worthy, D.: $\mathrm{CO}_{2}$ surface fluxes at grid point scale estimated from a global 21 year reanalysis of atmospheric measurements, J. Geophys. Res., 115, D21307, doi:10.1029/2010JD013887, 2010.

Ciais, P., Sabine, C., Bala, G., Bopp, L., Brovkin, V., Canadell, J., Chhabra, A., DeFries, R., Galloway, J., Heimann, M., Jones, C., Le Quèrè, C., Myneni, R., Piao, S., and Thornton, P.: Carbon and Other Biogeochemical Cycles, book section 6, 465-570, Cambridge University Press, Cambridge, UK and New York, NY, USA, doi:10.1017/CBO9781107415324.015, 2013.

Dalal, R. C., Wang, W., Robertson, G. P., and Parton, W. J.: Nitrous oxide emission from Australian agricultural lands and mitigation options: a review, Austral. J. Soil Res., 41, 165-195, doi:10.1071/SR02064, 2003.

DOA: Land use in Australia, Department of Agriculture, available at: http://www.agriculture.gov.au/abares/aclump/Documents/ Land_use_in_Australia_at_a_glance_2006.pdf (last access: 26 May 2015), 2006.

DOE: National Waste Reporting, Department of the Environment, available at: http://www.environment.gov.au/system/ files/resources/0a517ed7-74cb-418b-9319-7624491e4921/files/ overview-infrastructure_0.pdf (last access: 26 May 2015), 2013.

Enting, I. G.: Inverse Problems in Atmospheric Constituent Transport, Cambridge Univ. Press, New York, 67-76, 2002.

Fraser, A., Chan Miller, C., Palmer, P. I., Deutscher, N. M., Jones, N. B., and Griffith, D. W. T.: The Australian methane budget: Interpreting surface and train-borne measurements us- 
ing a chemistry transport model, J. Geophys. Res.-Atmos., 116, D20306, doi:10.1029/2011JD015964, 2011.

GA: Australian oil resources, Geoscience Australia, available at: http://www.ga.gov.au/scientific-topics/energy/resources/ petroleum-resources/oil (last access: 26 May 2015), 2010.

GA: Australian in situ coal resources, Geoscience Australia, available at: http://www.ga.gov.au/corporate_data/74097/74097.pdf (last access: 26 May 2015), 2012.

Gurney, K. R., Law, R. M., Denning, A. S., Rayner, P. J., Baker, D., Bousquet, P., Bruhwiler, L., Chen, Y., Ciais, P., Fan, S., Fung, I. Y., Gloor, M., Heimann, M., Higuchi, K., John, J., Maki, T., Maksyutov, S., Masarie, K., Peylin, P., Prather, M., Pak, B. C., Randerson, J., Sarmiento, J., Taguchi, S., Takahashi, T., and Yuen, C.: Towards robust regional estimates of $\mathrm{CO}_{2}$ sources and sinks using atmospheric transport models, Nature, 405, 626-630, doi:10.1038/415626a, 2002.

Hardt, M. and Scherbaum, F.: The design of optimum networks for aftershock recordings, Geophys. J. Int., 117, 716-726, doi:10.1111/j.1365-246X.1994.tb02464.x, 1994.

Haverd, V., Raupach, M. R., Briggs, P. R., J. G. Canadell., Davis, S. J., Law, R. M., Meyer, C. P., Peters, G. P., PickettHeaps, C., and Sherman, B.: The Australian terrestrial carbon budget, Biogeosciences, 10, 851-869, doi:10.5194/bg-10-8512013, 2013.

Lauvaux, T., Schuh, A. E., Uliasz, M., Richardson, S., Miles, N., Andrews, A. E., Sweeney, C., Diaz, L. I., Martins, D., Shepson, P. B., and Davis, K. J.: Constraining the $\mathrm{CO}_{2}$ budget of the corn belt: exploring uncertainties from the assumptions in a mesoscale inverse system, Atmos. Chem. Phys., 12, 337-354, doi:10.5194/acp-12-337-2012, 2012.

Law, R. M., Rayner, P. J., and Wang, Y. P.: Inversion of diurnally varying synthetic $\mathrm{CO}_{2}$ : Network optimization for an Australian test case, Global Biogeochem. Cy., 18, GB1044, doi:10.1029/2003GB002136, 2004.

Loh, Z. M., Law, R. M., Haynes, K. D., Krummel, P. B., Steele, L. P., Fraser, P. J., Chambers, S. D., and Williams, A. G.: Simulations of atmospheric methane for Cape Grim, Tasmania, to constrain southeastern Australian methane emissions, Atmos. Chem. Phys., 15, 305-317, doi:10.5194/acp-15-305-2015, 2015.

Lucas, D. D., Yver Kwok, C., Cameron-Smith, P., Graven, H., Bergmann, D., Guilderson, T. P., Weiss, R., and Keeling, R.: Designing optimal greenhouse gas observing networks that consider performance and cost, Geosci. Instrum. Method. Data Syst., 4, 121-137, doi:10.5194/gi-4-121-2015, 2015.

MLA: Australia's beef industry, Meet \& Livestock Australia, available at: http://www.mla.com. au/files/d0faf79a-7218-4f5a-85db-a1110102aaf8/

Cattle-Numbers-Map_as-at-June-2011.pdf (last access: 26 May 2015), 2011a.

MLA: Australia's sheepmeat industry, Meet \& Livestock Australia, available at: http://www.mla.com. au/files/15f9de69-f6ec-44c3-87b5-a1110102e972/

Sheep-Numbers-Map_as-at-June-2011.pdf (last access: 26 May 2015), 2011 b.

Myhre, G., Shindell, D., Breon, F.-M., Collins, W., Fuglestvedt, J., Huang, J., Koch, D., Lamarque, J.-F., Lee, D., Mendoza, B., Nakajima, T., Robock, A., Stephens, G., Takemura, T., and Zhang, H.: Anthropogenic and Natural Radiative Forcing, book section 8, Cambridge University
Press, Cambridge, UK and New York, NY, USA, 659-740, doi:10.1017/CBO9781107415324.018, 2013.

Nickless, A., Ziehn, T., Rayner, P. J., Scholes, R. J., and Engelbrecht, F.: Greenhouse gas network design using backward Lagrangian particle dispersion modelling - Part 2: Sensitivity analyses and South African test case, Atmos. Chem. Phys., 15, 20512069, doi:10.5194/acp-15-2051-2015, 2015.

NMOC: APS1 upgrade of the ACCESS-R Numerical Weather Prediction system, Tech. Rep. Operations Bulletin Number 98, National Meteorological and Oceanographic Centre, available at: http://www.bom.gov.au/australia/charts/bulletins/apob98.pdf (last access: 5 August 2015), 2013.

NRL: Bureau of Meteorology National Radar Loop: Weather Watch Radars, Bureau of Meteorology, available at: http://www.bom. gov.au/australia/radar/ (last access: 26 May 2015), 2014.

Peylin, P., Law, R. M., Gurney, K. R., Chevallier, F., Jacobson, A. R., Maki, T., Niwa, Y., Patra, P. K., Peters, W., Rayner, P. J., Rödenbeck, C., van der Laan-Luijkx, I. T., and Zhang, X.: Global atmospheric carbon budget: results from an ensemble of atmospheric $\mathrm{CO}_{2}$ inversions, Biogeosciences, 10, 6699-6720, doi:10.5194/bg-10-6699-2013, 2013.

Rayner, P. J., Enting, I. G., and Trudinger, C. M.: Optimizing the $\mathrm{CO}_{2}$ observing network for constraining sources and sinks, Tellus B, 48, 433-444, doi:10.1034/j.1600-0889.1996.t013-00003.x, 1996.

Rayner, P. J., Scholze, M., Knorr, W., Kaminski, T., Giering, R., and Widmann, H.: Two decades of terrestrial carbon fluxes from a carbon cycle data assimilation system (CCDAS), Global Biogeochem. Cy., 19, GB2026, doi:10.1029/2004GB002254, 2005.

Rayner, R. J: Optimizing $\mathrm{CO}_{2}$ observing networks in the presence of model error: results from TransCom 3, Atmos. Chem. Phys., 4, 413-421, doi:10.5194/acp-4-413-2004, 2004.

Rayner, P. J., Raupach, M. R., Paget, M., Peylin, P., and Koffi, E.: A new global gridded data set of $\mathrm{CO}_{2}$ emissions from fossil fuel combustion: methodology and evaluation, J. Geophys. Res., 115, D19306, doi:10.1029/2009JD013439, 2010.

Seibert, P. and Frank, A.: Source-receptor matrix calculation with a Lagrangian particle dispersion model in backward mode, Atmos. Chem. Phys., 4, 51-63, doi:10.5194/acp-4-51-2004, 2004.

Tarantola, A.: Inverse Problem Theory: Methods for Data Fitting and Model Parameter Estimation, Elsevier, Amsterdam, 41-60, 1987.

Uliasz, M.: Lagrangian particle modeling in mesoscale applications, in: Environmental Modelling II, 71-102, Computational Mechanics Publications, 1994.

Wang, Y. P., Law, R. M., and Pak, B.: A global model of carbon, nitrogen and phosphorus cycles for the terrestrial biosphere, Biogeosciences, 7, 2261-2282, doi:10.5194/bg-7-2261-2010, 2010.

WMO: The Global Atmosphere Watch Programme: 25 Years of Global Coordinated Atmospheric Composition Observations and Analyses, Tech. Rep. WMO-No. 1143, World Meteorological Organization, Geneva, Switzerland, 2014.

Ziehn, T., Scholze, M., and Knorr, W.: Development of an ensemble-adjoint optimization approach to derive uncertainties in net carbon fluxes, Geosci. Model Dev., 4, 1011-1018, doi:10.5194/gmd-4-1011-2011, 2011.

Ziehn, T., Nickless, A., Rayner, P. J., Law, R. M., Roff, G., and Fraser, P.: Greenhouse gas network design using backward Lagrangian particle dispersion modelling - Part 1: Methodology 
and Australian test case, Atmos. Chem. Phys., 14, 9363-9378, doi:10.5194/acp-14-9363-2014, 2014. 